\title{
DICTION OF SASAK STUDENT INTERACTIONS IN ISLAMIC BOARDING SCHOOL
}

\author{
Ahmad Sudali', Yulianah Prihatin ${ }^{2}$ \\ Pendidikan Bahasa dan Sastra Indonesia, Fakultas Ilmu Pendidikan, Universitas Hasyim Asy'ari \\ Corresponding Author: ${ }^{1}$ Ahmadsudali51@gmail.com
}

\begin{abstract}
The purpose of this study was to determine the use of Sasak students in communication at the Darul Falah III Cukir-Jombang Roudlotul Qura'an Islamic Boarding School and in areas around Tebuireng. This study uses a qualitative research approach. The data obtained are in the form of oral data and data or image recordings that are carried out when the objects interacting about the use of Indonesian by Sasak students in both official and casual forums. The results of the research will be described or written in the form of a report, the data that has been collected will be collected, analyzed, described and will be removed as best as possible to answer the problem formulation in order to achieve all the objectives in this study properly. The result of the research is that the diction contained is diction related to meaning, namely diction based on denotative, and diction based on connotative meaning.
\end{abstract}

Keywords: Diction, Interaction

\section{PENGGUNAAN DIKSI MAHASISWA SASAK DALAM INTERAKSI DI PONDOK PESANTREN}

\begin{abstract}
Abstrak
Tujuan penelitian ini adalah untuk mengetahui pemakaian diksi mahasiswa sasak dalam komunikasi di Pondok Pesantren Roudlotul Qura'an Darul Falah III Cukir-Jombang dan diwilyah sekitar Tebuireng. Penelitian ini menggunakan pendekatan penelitian kualitatif. Data yang diperoleh berupa data lisan dan data rekaman atau gambar yang dilakukan ketika objek penelitian melakukan interaksi tentang pemakaian bahasa Indonesia oleh mahasiswa Sasak baik di dalam forum resmi maupun santai. Hasil penelitian nantinya akan dideskripsikan atau ditulis kedalam bentuk laporan, data yang sudah terkumpulkan akan di identifikasi, dianalisis, dideskripsikan dan akan disimpulkan sebaik mungkin untuk menjawab rumusan masalah agar tercapai semua tujuan dalam penelitian ini dengan baik. Adapun hasil penelitian diperoleh bawha diksi yang terkandung yaitu diksi yang berkaitan dengan makna, yaitu diksi berdasarkan makna denotatif, dan diksi berdasarkan makna konotatif.
\end{abstract}

Kata Kunci: Diksi, Interaksi

\section{PENDAHULUAN}

Dalam berbahasa seseorang tidak lepas dari kebiasaan dialek, logat dan tutur kata yang dilontarkan ketika berbicara, hal ini menjadikan ciri khas dalam berbahasa karena masih terbawa kebiasaan bahasa lingkungan yang sangat sulit dilepas, namun dalam hal itu menjadikan sebuah keunikan dalam bertutur kata dari setiap orang yang sukunya berbeda-beda, dalam berbahasa seperti ini menjadi salah satu kendala untuk memakai bahasa resmi yang memang seharusnya setiap orang sebagai warga negara yang baik harus mampu mengusai bahasa resmi bangsanya sendiri, dalam hal ini terlihat dengan jelas ketika seseorang berkomunikasi terlebih-lebih lawan bicaranya adalah berasal dari suku yang 
sama seperti mahasiswa Sasak yang tinggal di Pondok Pesantren Roudlotul Qur'an Darul Falah III Cukir-Jombang, bahasa daerahnya yang masih kental menyebabkan bahasa resmi sulit untuk dikuasai sepenuhnyaketika bertutur sekalipun dalam lingkup yang resmi, bahasa seperti itu akan sering muncul atau sering dipakai ketika seseorang berbicara dan sulit untuk menemukan kata-kata yang ada didalam bahasa Indonesia sehingga untuk melancarkan dan mempermudah diri berbicara dengan menyambung kata-kata yang sulit dengan memakai bahasa daerah asal usul yang biasa disebut dengan nama bahasa suku atau bahasa daerah. Percampuran bahasa yang sering digunakan ketika seseorang berbicara memakai bahasa Indonesia namun tidak sepenuhnya memakai bahasa Indonesia karena diselasela pembicaraannya sering terjadi tambahan kata-kata atau bahasa yang lain seperti bahasa Sasak, bahasa Jawa, bahasa Inggris dan juga bahasa Arab hal ini sering terjadi pada interaksi mahasiswa Sasak di Pondok Pesantren Roudlotul Qur'an Darul Falah III. Padahal dalam setiap interaksi atau percakapan merupakan kesalahan patal bagi seorang pelajar kalau dikaitkan dengan bahasa resmi yang merupakan bahasa persatuan bagi bangsa Indonesia.

Eksistensinya dalam penggunaan bahasa Indonesia memang sebagai bahasa resmi dan bahasa persatuan dalam bernegara yang merupakan bahasa seharihari yang dipakai dalam berkomunikasi khususnya dalam acara atau ditempat yang resmi, namun perlu dilihat bahwa bangsa Indonesia merupakan negara kesatuan yang majemuk dan mempunyai banyak suku bangsa dan bahasa, di setiap daerah mempunyai bahasa masing-masing khususnya seperti bahasa Sasak yang dalam hal ini merupakan objek yang diteliti oleh peneliti, dengan kontak bahasa antar daerah akan menyebabkan percampuran dalam berbahasa yang biasa disebut dengan dwibahasa atau disebut juga dengan campur kode dan alih kode, kejadian-kejadian seperti ini menyebabkan peneliti penasaran dan ingin mengkaji lebih dalam khususnya diksi yang dipakai pada interaksi mahasiswa Sasak yang ada di Pondok Pesantren Roudlotul Qur'an Darul Falah III CukirJombang.

\section{LANDASAN TEORI}

Munculnya ilmu sosiolinguistik diakibatkan dari adanya eksplotasi kebahasaan secara teoritik dan normatif berabad-abad yang lalu, sehingga menempatkan bahasa secara khsusus yang terpisah dari masyarakat, pemikiran seperti ini menempatkan pemakaian bahasa dengan tidak langsung secara hitam putih, bahasa yang tidak sesuai dengan norma masyarakat dipandang sebagai sesuatu yang menyimpang, bahasa masyarakat secara tidak formal (lisan) pada umumnya berbentuk pragmen-pragmen dan ujaran yang ekspresif, sulit bersifat denonantif dan tidak termasuk dalam makna dan diluar bahasa seperti yang sering ditemukan di masyarakat. Kegagalan seperti inilah pada akhirnya akan menjadi salah satu alasan untuk dilakukan pengkajian ulang secara konvensi teoritik yang ada dan akan menimbulkan diskusi di kalangan para ahli atau pakar linguis dan praktis bahasa. Namun bahasa yang sering di gunakan oleh masyarakat yang pada dasarnya tidak sesuai dengan prinsip kebahasaan (normatif) itu kadang berlangsung terus menerus dan tidak pernah ada permasalahan yang signifikan didalam berkomunikasi sehari-hari namu dengan kehadiran kedisiplinan ilmu sosiolinguistik dalam rangka untuk memberikan analisis secara alternatif terhadap proses komunikasi masyarakat secara lisan dan tidak akan tepecahkan melalui kajian normatif, karena pada dasarnya objek ilmu sosiolinguistik adalah kebahasaan masyarakat dalam keseharian ketika berbicara (Basir, U. P.M , 2017: 118). 


\section{Konsep / Definisi}

Sosiolinguistik merupakan ilmu yang mempelajari dan mempengaruhi sosial terhadap pemkaian bahasa yang digunakan oleh masyarakat dan efek penggunaan bahasa dalam masyarakat tersebut. Sosiolinguistik berbeda dengan sosiologi namun kedua ilmu ini berkaitan erat dan tidak bisa dipisahkan karena pada dasarnya ke dua ilmu ini sama-sama mempelajari dan mengakaji tentang masyarakat namun ilmu sosiolinguistik lebih fokus pada efek sosial dan bahasa yang digunakan oleh masyarakat ketika berkomunikasi, ilmu sosiolinguistik juga mempelajari keberagaman bahasa yang berbeda, antara kelompok yang satu dengan kelompok yang lainnya, bangsa yang satu dan bangsa yang lain dan juga antara suku dengan suku lainya. Sebenarnya ilmu sosiolinguistik sangat luas pembahasannya namun terdapat beberapa konsep dasar yang ada dalam sosiolinguistik diantara lain:

\section{a. Komunitas berbicara}

Komunitas berbicara adalah konsep yang mendeskripsikan atau meneliti sebuah kelompok tertentu yang memakai bahasa dengan cara unik dan dapat diterima dalam komunitas masyarakat tersebut, komunitas berbicara dapat menjadi anggota diantara masyarakat ketika ada kegiatan ikut dengan mereka dan mengikuti alur masyarakat.

b. Jaringan sosial

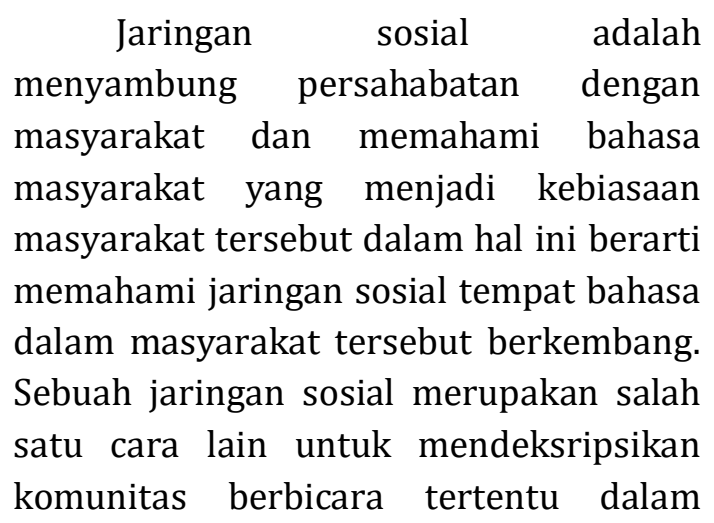

hubungan antar individu dalam komunitas yang ada di dalam masyarakat. Sebuah jaringan sosial masyarakat dapat ketat atau longgar tergantung bagaimana anggotanya berinteraksi antara satu dengan yang lainnya, saat ini karena zaman sudah moderan, menjalin hubungan sosial juga bisa tercipta melalui sosial media seperti internet, group Facebok, ruang chat dll.

\section{c. Keberagaman reputasi}

Bahasa dalam masyarakat atau sosial bisa dibedakan berdasarkan nilai positif dan negatif atau tinggi dan rendahnya dalam pandangan masyarakat itu sendiri, ada juga jenis bahasa yang menggambarkan reputasi lebih tinggi dalam anggapan masyarakat dan ada juga yang menggambarkan reputasi kelompok yang lebih rendah tergantung masyarakat itu sendiri karena penilian suatu bahasa tergantung kebiasaan masyarakat setempat yang memakai bahasa itu, seperti di Lombok atau di Jawa, misalnya bahasa yang digunakan di kalangan bangsawan dengan masyarakat biasa berbeda dari segi dialek, jenis bahasa yang digunakan dan cara penuturannya atau ungkapan ketika seseorang berbahasa namun semua itu tidak lepas dari nilai pandang masyarakat setempat.

\section{Persentuhan Bahasa}

Hubungan antar suku dan bangsa yang sudah berlangsung sejak puluhan tahun bahkan ribuan tahun menyebabkan adanya saling ketergantungan kepentingan dan sarana hubungan yang berimbas pada terjadinya persentuhan budaya dan bahasa dikalangan masyarakat. Kontak budaya yang berlangsung sebenarnya sudah demikian lama, hal itu menyebabkan terjadinya asimilasi antara budaya dan bahasa. Antar pemakai bahasa yang saling mempertukarkan unsur bahasa baik secara 
sadar maupun secara tidak sadar kejadian yang demikian menyebabkan terjadinya persentuhan bahasa dalam setiap bangsa.

\section{Kedwibahasaan}

Hampir dipastikan sangat sulit sekali dijumpai bahasa yang murni di dunia ini, tanpa ada pengaruh dari bahasa daerah dan bahasa bangsa lain, hubungan antar suku bangsa yang menjalin hubungan dengan baik sejak ribuan tahun akan menyebabakan saling ketergantungan kepentingan dan hal itu akan berimbas pada persentuhan budaya yang akan mengaikbatkan dalam berbahasa secara tidak murni, kontak budaya yang berlangsung begitu lama akan menyebabkan asimilasi antar budaya dan bahasa, antar pemakaian bahasa saling mempertukarkan unsur bahasa lain baik dengan secara sadara maupun secara tidak sadar. Tipologi masyarakat yang demikian itu disebut dengan masyarakat dwibahasaan, mereka menggunakan lebih dari satu bahasa dalam proses berkomunikasi sehari-hari di masyarakat (Basir, U. P.M, 2017: 23).

Kedwibahasaan atau disebut dengan bilingualisme dalam perkembangannya banyak sekali mengalami perubahan makna, hal itu disebabkan dikarenakan latar belakang seseorang menjadi dwibahasawan bersifat nisbi satu sama lain berbeda-beda demikian juga mereka yang selalu menaruh perhatian terhadap bidang ini akan menggunakan pendekatan yang berbeda dan bekal disiplin ilmu (spesifikasi) yang tidak akan sama (Basir, U. P.M, 2017: 24).

\section{METODOLOGI PENELITIAN}

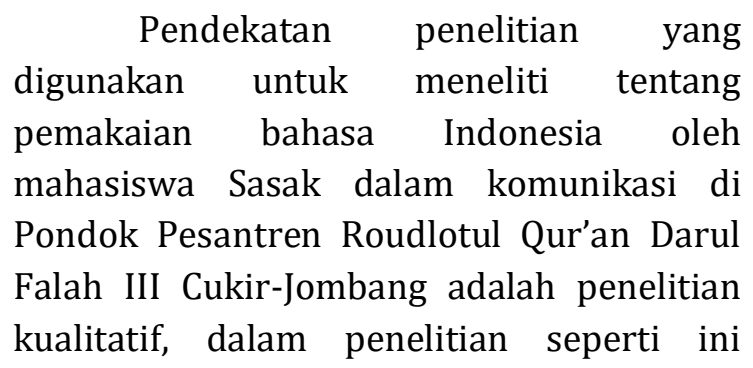

didasari pada proses pengambilan data. Data yang diperoleh berupa data lisan dan data rekaman atau gambar yang dilakukan ketika objek penelitian melakukan interaksi tentang pemakaian diksi bahasa Indonesia oleh mahasiswa Sasak baik di dalam forum resmi atau santai dan hasil penelitian nantinya akan dideskripsikan atau ditulis kedalam bentuk laporan, data yang sudah terkumpulkan akan di identifikasi, dianalisis, dideskripsikan dan akan disimpulkan sebaik mungkin untuk menjawab semua rumusan masalah agar tercapai semua tujuan dalam penelitian ini dengan baik. Penelitian kualitatif merupakan penelitian yang bertujuan untuk memahami dan meneliti fenomena apa yang dialami atau pengalaman selama melakukan penelitian berlangsung oleh subjek dalam meneliti, dengan cara mendeskripsikan dengan sebaik mungkin dalam bentuk kata kata yang tepat dan bahasa yang mudah untuk dipahami dan dalam penelitian ini berbentuk khusus tidak dicampur adukkan dengan metode penelitian lain. Teknik pengumpulan data pada penilitian ini yaitu teknik observasi, wawancara, perekaman dan dokumentasi.

Analisis data yang dilakukan dalam penelitian ini merupakan data yang diperoleh dari hasil observasi, wawancara, perekaman dan dekomendasi yang mempunyai tahapan-tahapan tertentu dalam mengklasifikasikan data yang telah dikelompokkan dan yang telah dianalisis dengan baik, namun dalam menganalisis data dalam penelitian ini karena peneliti memakai penelitian kualitatif maka penganalisisan data akan dilakukan saat pengumpulan data berlangsung setelah pengumpulan data selesai dalam periodepriode tertentu yang menjadi sebuah proses saat pengumpulan data pada saat melakukan wawancara dan dekomendasi, setelah peneliti melakukan penganalisisan terhadap jawaban pada data yang diteliti, maka apabila jawaban objek yang 
diwawancarai terasa belum pas atau tidak memuaskan sesuai dengan keinginan wawancara yang dilakukan maka peneliti akan mengulangi untuk melakukan penelitian lagi sampai waktu tertentu, namun dalam penelitian ini memerlukan waktu agak lama sehingga peneliti sampai peneliti mendapatkan data yang dianggap kredibel yang memuaskan sesuai dengan keinginan dan tujuan penelitian yang dilakukan (Sugiono, 2018: 246). Berdasarkan pendapatnya Miles dan Huberman (Sugiono, 2018: 246), mengatakan bahwa selama aktivitas dalam penganalisisan data kualitatif dilakukan dengan cara interaktif dan berlangsung secara terus menerus sampai tuntas sehingga datanya lengkap dan juga datanya sudah jenuh sehingga tidak perlu diulangi lagi. Dalam penganalisisan peneliti menggunakan cara pengumpulan data dengan beberapa tahapan sebagai berikut: 1) pengumpulan data, 2) pereduksian data, 3) penyajian data, dan, 4) penarikan kesimpulan (verifikasi) dengan memanfaatkan triangulasi sebagai cara pengecekan keabsahan data temuan.

\section{PEMBAHASAN}

Berdasarkan hasil penelitian didapatkan beberapa diksi yang terdapat pada interkasi mahasiswa Sasak di Pondok Pesantren Darul Fallah III. Diksi adalah suatu pilihan kata yang sangat tepat dan selaras dengan penggunaannya dalam menyampaikan sebuah gagasan, ide atau cerita yang meliputi tentang gaya dalam bahasa, pilihan kata atau ungkapan, dll. Sehingga didapatkan efek sesuai dengan yang diinginkan, diksi mempunyai bagianbagian yang cukup banyak seperti Diksi Berdasarkan Maknanya dan Diksi Berdasarkan Leksikal. Diksi Berdasarkan Maknanya dibagi menjadi dua (1) Makna Denotatif yaitu diksi yang berkaitan dengan makna yang sebenarnya dari suatu kalimat atau kata. (2) Makna Konotatif yaitu diksi yang berkaitan dengan kalimat atau kata yang memiliki makna bukan yang sebenarnya. Diksi Berdasarkan Leksikal juga mempunyai bagian tersendiri seperti Sinonim, Antonim, Homonim, Homofon, Homograf, Polisemi, Hipernim dan Hiponim. Beberapa diksi dan bagian-bagian yang sudah disebutkan diatas, peneliti tidak menemukan semua itu didalam tuturan mahasiswa Sasak yang berada di Pondok Pesantren Roudlotul Qur'an Darul Falah III, namun peneliti menemukan diksi dalam tuturun mahasiswa Sasak sebagai berikut:

1. Diksi berdasarkan makna denotatif, diksi ini biasanya berkaitan dengan makna yang sebenarnya, ketika bertutur seseorang akan menggunakan tuturan yang langsung pada apa yang dituturkan sehingga dalam tuturan tidak memakai bahasa kiasan, untuk lebih jelas dalam memahami diksi denotatif. Berikutbeberapa kutipanyangmenggambarkan.

a) Kode data dd 20.

Akbar: "mudik kabbeh" (mudik semuanya). Konteks: menjawab apa yang di katakan Habi sambil membantu teman-temannya yang sedang membereskan barangnya.

b) Kode data dd 20 .

Nasar: "mana kucinya"

Konteks: meminta sama Habi dengan menjulurkan tangan sebe lah kanan dan tangan sebelah kiri membawa koper yang akan ia bawa memakai sepeda motornya Habi.

c) Kode data dd 25.

Habi: "hijau itukan landasan NU gitu loh, maksudnya kemarin"

Kontek: berbicara keteman-temannya dengan wajah serius dan menambahkan apa yang telah disampaikan Wahid.

Berdasarkan data 1, 2 dan 3 dengan kode data dd 20, dd 20 dan kode data dd 25. Didapatkan bahwa mahasiswa Sasak yang berada di Pondok Pesantren Roudlotul 
Qur'an Darul Falah III Cukir-Jombang dan mahasiswa Sasak yang tinggal diwilayah Tebuireng ketika bertutur terjadinya diksi berdasarkan makna denotatif, karena ketika mahasiswa Sasak bertutur bersama temantemannya seringkali tuturan itu diungkapkan dengan makna yang khususnya pembaca karena dalam hal ini berkaitan dengan tulisan, maka akan lebih cendrung untuk menggunakan katakata yang denotatif, sebabab dengan bahasa denotatif pengarahannya yang lebih jelas terhadap fakta khususnya tujuan utamanya (Keraf, 2010. 28).

2. Diksi berdasarkan makna konotatif, diksi ini juga peneliti temukan didalam tuturan mahasiswa Sasak ketika sedang bertutur bersama teman-temannya, dalam diksi makna konotatif biasanya berkaitan dengan makna yang bukan makna yang sebenarnya atau bisa disebuat dalam tuturan atau bahasa kiasan, untuk lebih jelas dalam memahami diksi konotatif. Berikutbeberapakutipan yang menggambarkan.

a) Kode data dd 20

Tantowi: "kan mirip herensi naga"

Konteks: menambahkan pembi caraannya yang dipotong sama Akbar yang belum selesai sambil melipat pakaian dan dimasukkan kedalam koper.

b) Kode data dd 30

Azra,i:"endek ape uning ngenukn, endekn wah beu arak idap ilmun wah suang milu, adekn kanak gejek iku,leguk tenyobak" (gak saya nyindir, beru merasa punya ilmu sudah gak mau ikut lagi, biarkan anak kecil itu, tapi kita coba"

Konteks: menyambung pernyataan Fawaz yang diungkapkan. sebenarnya tapi bukan berarti tidak memakai bahasa sindiran atau kiasan. Dalam bentuk yang murni biasanya makna denotatif dihubungkan dengan bahasa ilmiah, ketika seorang penulis menyampaikan informasi kepada kita

c) Kode data dd 30

Azrai: "marak uning sak beruk harus marak power rangers, teberubah jolok" (apayang saya katakana tadi, seperti power rangers, kita berubah dulu).

Konteks: melanjutkan pembicaraan yang sebelumnya sambil mengelus elus ibu jari kakinya yang sebelah kiri.

Berdasarkan data 1, 2 dan 3 dengan kode data dd 20, Dd 30 dan kode data dd 30. Didapatkan bahwa mahasiswa Sasak yang berada di Pondok Pesantren Roudlotul Qur'an Darul Falah III Cukir-Jombang dan mahasiswa Sasak yang tinggal diwilayah Tebuireng ketika bertutur terjadinya diksi yang berkaitan dengan makna konotatif, karena mahasiswa Sasak termasuk orangorang yang berpendidikan tinggi sehingga ketika bertutur terkadang adanya tuturan atau bahasa kiasan yang dipakai, dalam hal ini berkaitan erat dengan makna konotatif. Makna konotatif merupakan suatu jenis makna setimulus dan respons dengan mengandung nilai-nilai emosional, makna konotatif biasanya terjadi karena pembicaraan ingin menimbulkan persaan yang setuju atau tidak setuju, senang ataupun tidak senang dan sebaginya kepada pihak pendengar dipihak lain, biasanya kata yang dipilih adalah kata-kata kiasan atau perumpamaan sehingga memperlihatkan bahwa pembicaraan memendam perasaan yang sama (Keraf, 2010. 29).

dengan makna yang terdapat dalam tuturan mahasiswa Sasak yaitu, 1) Diksi berdasarkan makna denotatif dan 2) Diksi berdasarkan makna konotatif. 
Jurnal DISASTRI (Pendidikan Bahasa dan Sastra Indonesia)

Volume 3, Nomor 1, April 2021| P-ISSN : 2716-4114 | E-ISSN: 2722-3329

\section{DAFTAR PUSTAKA}

Basir, U. P.M. 2017. Sosiolinguistik Pengantar Kajian Tindak Berbahasa. Surabaya: CV Kartika Mulya.

Keraf, Gorys. 2010. Diksi dan Gaya Bahasa. Jakarta: PT Gramedia Pustaka Utama.
Sugiono. 2018. Metode Penelitian Kuantitatif, Kualitatif, dan $R \& D$. Bandung: ALVABETA, cv 